\title{
The Figure of the Nenek Kebayan and the Witch in Selected Haunted House Films
}

\author{
AHMAD MUHYIDDIN YUSOF \\ Universiti Teknologi MARA (UiTM), \\ Cawangan Perak, Malaysia \\ ANITA HARRIS SATKUNANANTHAN (Corresponding Author) \\ Universiti Kebangsaan Malaysia, Malaysia \\ aharris@ukm.edu.my \\ RUZY SULIZA HASHIM \\ Universiti Kebangsaan Malaysia, Malaysia \\ NURLIYANA MOHMAD RUSLI \\ Kolej Felcra, \\ Perak Darul Ridzuan, Malaysia
}

\begin{abstract}
This study analyses the Malay folkloric trope of the Nenek Kebayan and how this supernatural figure is connected to the Gothic trope of the haunted house in selected horror films. This study contends that the figure of the Nenek Kebayan is instrumental in the haunting effect of these homes. Three horror films have therefore been chosen to analyse the motif of the Nenek Kebayan and the haunted house which are Congkak (2005), Al-Hijab (2011) and additionally, the figure of the Nenek Kebayan is compared to the figure of the spectral Witch in The Conjuring (2013). In so doing, this study adapts the Structural Uncanny Haunted House Framework (SUHHF) as a theoretical framework. SUHHF is an Uncanny adaptation of Joshua Comaroff's and Ong Ker-Shing's concept of the architecture of horror. SUHHF focuses primarily on three aspects of the haunted house which are The Surmounted Corpse that provides insights to the external and internal layer of the house, The Hazardous Transition that explains the application of the transitional elements of the haunted house and finally the Trojan Compartment that reveals the secret spaces in the haunted house. Furthermore, filmic technique is deployed as a methodology to capture the moments of haunting by the Nenek Kebayan and her cognate, the Witch. The implication of this study to provide a deeper appreciation and understanding in regards to aspect of the Nenek Kebayan and the haunted house setting in the examined films.
\end{abstract}

Keywords: haunted house; Nenek Kebayan; hauntings; convergence; divergence; the Witch

\section{INTRODUCTION}

This article considers and analyses the role of the Nenek Kebayan in selected films of Malaysian origin, including the American-produced film The Conjuring. Horror as a genre has resonated with popular consciousness because it taps into the collective psyche and the fears contained within that psyche. Xavier Aldana Reyes (2016, p.7) writes that the word etymologically derives from "the Latin verb horrere, to tremble or shudder". Reyes further comments that horror is used in texts and narratives to "generate fear, shock or disgust" and a combination thereof $(2016$, p.7). One may ask why an author or director may wish to excite such feelings in the reader or audience -- this question may be inferred in this article's interrogation of the haunted house narrative in horror movies of Malaysian origin. Brittany (2017, p.93) writes that the connectivity between horror films and audience's experiences as "horror films relay horrific experiences to an audience through modes of character-driven storytelling." Here, each character plays an important role in experiencing, exploring and delivering the hauntings in the film to the audience. Furthermore, horror film productions 
explore and exploit real-life horror experiences in order to create and bridge meaningful horrific experiences between the audiences and the characters (Kaay and Vander Kaay, 2013, p.7). In the general run of things, especially in the Malaysian context, the Pontianak or perhaps the Langsuir commonly appear as the apex ghost in countless horror films especially in the haunted house setting. Typical appearances of the Pontianak or the Langsuir terrorizing and inhabiting haunted houses may be found in films such as Puaka Balai Gombak by Wan Hafiz in 2015 and Villa Nabila by Syafiq Yusof in 2015. Both films tell of a group of supernatural enthusiasts's attempt to prove the existence of Pontianak and Langsuir. Unfortunately, they met an untimely demise owing to their supernatural endeavours. Although these two supernatural figures commonly appear in numerous horror films and settings, there is another horror figure who possesses equal footing with the Pontianak and Langsuir, which is the Nenek Kebayan, the wise old woman of the woods of Malay folklore, and who may be read as a cognate of the supernatural manifestation of the occidental Witch, oft-demonised in horror movies. The primary intention of this paper is therefore to discern the role of the Nenek Kebayan in the setting in haunted house films of Malaysian origin and how these supernatural depictions of the Nenek Kebayan correlate with that of the Witch in popular horror films. In unravelling this predicament, this paper deploys the Structural Uncanny Haunted House Framework (SUHHF) as the choice of framework to investigate behaviours and nature of the Nenek Kebayan in delivering spectral disturbances towards the inhabitants of the house. This article interrogates the ways in which the figure of the Nenek Kebayan is central to the haunted house motif within the three horror films selected as the corpus for this research. Three horror films have been identified that have the element of the Nenek Kebayan and the haunted house which are Congkak directed by Ahmad Idham (2005), Al-Hijab directed by Pierre Andre (2011) and The Conjuring directed by James Wan (2013). Although James Wan's The Conjuring was produced in the United States of America, the director himself is of Malaysian origin, and in acknowledging this fact, he is included within this corpus particularly owing to the fact that the movie has a supernatural depiction of a Witch. The criterion for choosing the stated corpus are the appearance of the Nenek Kebayan as a motif (or in the case of The Conjuring, a cognate of the Nenek Kebayan)and the haunted house as the primary setting, as it is used to analyse the Nenek Kebayan's behaviour and influence within the haunted house.

\section{LITERATURE REVIEW}

The fundamentals in understanding the notion of the supernatural, Hantu and Nenek Kebayan is central to the lifestyle of the traditional Malays. The traditional Malay community or Masyarakat Melayu during the era of pre-colonial and colonial, they have vast lands on a wide scale and traditional personal belongings such as the Keris, Tepak Sirih, gold ornaments and traditional porch games such as the Batu Seremban and the Congkak. Mohd Faizal Omar writes that to preserve and protect their ownership, the pre-colonial Malays sought the aid of spiritual guardians (2014, p.11). These spiritual guardians according to the Islamic perspective is called Jin (Djinns), Saka or the Hantu Raya (Mohd Faizal Omar, 2014, p.11). These Djinns obey their masters when they have made a pact where the master gives offerings to these spiritual guardians such as Ayam Panggang (roasted chicken), Pulut Kuning (glutinous rice) and Telur Rebus (boiled eggs). Furthermore, according to Mohd Faizal Omar (2014, p. 11) after offering, these creatures will do their master's biddings such as guarding their lands, cleaning and harvesting the master's lands. Other than having spiritual guardians, the traditional Malays also have their own belief in which every land, tree and object has its own spiritual guardian that are either inhabited or guarded by it and became the source of supernatural power (Sajise and Doolittle, 2011, p.50). In relation to this, the Malays believe that whoever possesses ill 
intentions to either transgress or steal, the spiritual guardian would manifest to protect the property by scaring them away or inflicting pain and disease towards the evil-doers. Apart from the Hantu Raya or Saka, the Nenek Kebayan is a figure who also possesses supernatural attributes almost similar to that ascribed to the spiritual guardian. According to Othman Putih and Aripin Said (2007, p.20) the Nenek Kebayan was originally known as a mystical guardian who commonly appears in the Malay lore; one of the appearances of the Nenek Kebayan in the Malay lore in which she tends to the welfare of the Puteri Tiga Beradik (The three princess). In relation to this, suggested by Sharifah Aishah Osman (2020), other appearances of the Nenek Kebayan may be seen in various versions of the Puteri Gunung Ledang (The Princess of Gunung Ledang) legend where she appears or manifests in the form of an old lady with five hunchbacks negotiating with Hang Tuah for Puteri Gunung Ledang's hand of marriage for the Malay Sultan in the sixteenth century. Mohd. Azhar Abd. Hamid (2007, P.111) writes that during the negotiation the Nenek Kebayan demanded ridiculous dowries such as building a golden bridge and seven trays of mosquitoes' heart. Other roles that have been performed by this mystical guise in the Malay lore are as cautionary or a figure of warning, the exemplar of tradition, the mystical healer, children's counsellor, a therapist and also as respected community elder (Sharifah Aishah Osman, 2020, P.175).

Conversely, some perspectives claim that the Nenek Kebayan is not the guardian archetype, but a shadow archetype instead. Mentioned by Peletz (1996, p.370) the Nenek Kebayan is a grandmother spirit who resides alone in the jungle or forest. In relation to this, Sanjay Krishnan (2007, p.101) the Nenek Kebayan is a spirit of "the rice planting old lady". The Nenek Kebayan is not just a figure of past folklore but there are newspaper reports claiming that the Nenek Kebayan haunts human beings. Reported by Harian Metro dated on November 2016, in FELDA Pasoh Negeri Sembilan, children have been frequently haunted and possessed by the Nenek Kebayan. Some locals refer the Nenek Kebayan that haunts their children as the Nenek Harimau, children that have been reportedly haunted by this mystical guise showing symptoms of possession (Harian Metro, 2016). Abdullah Bukhari Abdul Rahim Al-Hafiz (2012) suggests the guise of the Nenek Kebayan and other Hantu in the Malay lore are a subcategory of djinn. These djinns promise on the demise of Muslims by diverting their faith (Berita Harian Online, 2015). Largely, in the context of the Malay world, the Nenek Kebayan is a spirit that appears in the form of an old lady that resides in the forest in which functions to either divert the Muslim faith, a wise mystical guise or an evil guardian of the forest.

In discussing the episode of the Nenek Kebayan in the Western context, this mystical personage may be compared to the witch. Witches have a different set of conventions in comparison to the Malaysian Nenek Kebayan. Instead of a supernatural guise, a witch is an individual who practices, masters, dwells and bonds with the supernatural (Bane, 2012, p.1). Summers (2012, p.12) asserts that the witch possesses the knowledge of a necromancer (the one who is able to gain revelation from the dead, foretelling and divination), a sorcerer (the one who practices magic arts and enchantment) and sometimes more controversially, accused of being a Satanist (the one who devotes himself or herself to Satan). Bane (2012, p.1) comments that witch's identity is not complete without her familiar. Grimassi (2003, p. 2) notes that the witch's familiar primarily functions as a mediator in the spirit world. Guiley (2008, P.123) elucidates that the varieties of witch's familiar range from black cats, dogs and to even creepy crawlers such as cockroaches and ants. The witch also shares a few similarities with the Nenek Kebayan -- the witch also appears in folklores and has healing abilities.

The witch figure has appeared in a plethora of folktales and mythologies. In fact, in most episodes of the witch's appearance is as an antagonist. An example may be found in William Shakespeare's Macbeth. The three witches appear in front of Macbeth giving premonition on Macbeth's rise to the throne (Cahn, 1996, p.181). Unfortunately, the premonition of three witches may be read as nothing more than a lie since the witches are only 
toying with Macbeth's vulnerability (Cahn, 1996, p.181). Cahn (1996, p.181) further explains that the figure of the witch has generally been associated with evil due to her ability to fly, to vanish, conjure spirits, storms, curses and inflict diseases. Like the Nenek Kebayan, this magical woman is therefore demonized because of her supernatural abilities and seen as being in league with the devil because she operates outside of patriarchal dictates and challenges those dictates.

Another sinister appearance of the witch may be seen in one of the European classics written by the Grimm Brothers in the $19^{\text {th }}$ century entitled Hansel and Gretel, a tale of two siblings lured by a witch who resides in a gingerbread house in a forest, ensorcelling them with sweets and candies only to fatten them up to be consumed. In Russian folktales, the witch is known as the Baba Yaga (the wild witch of the east) or perhaps known as the, Baba-Liaga, Liaga-Baba (Johns, 2010, p.53) or the Babushka which means the grandmother (Forrester, 2013, p.XXI). The habitat of the Baba Yaga is somewhere within the Russian forest, living together with her daughter Marinushka in an old hut on a chicken leg (John, 2010, p.53). The Baba Yaga who is cast in the role of the antagonist is generally deployed to scare naughty children into behaving well (Bane, 2016, p.30). Bane (2016, p.30) furthers her explanation by expounding that the figure of the Baba Yaga is used as a stimulus or threat to enforce discipline among naughty children, the children will be kidnapped by the Baba Yaga and put into her sack only to be eaten in her hen-legged hut. A similar notion to the short story entitled the Sandman by Hoffman. Freud (2003, p.136) commented that, the figure or perhaps the story itself threatens naughty children to sleep early if not the sandman will come and sprinkle burning coal onto their eyes. Despite these exaggerated depictions of witch's traits there are in popular culture and in mythology, witches with humane traits. For example, in Greek mythology, the witch Medea was recorded to brew healing potions to cure the Argonaut's wound during battle (Stang, 2015, p.31).

The ambiguity of the figure of the witch who is both demonized and occasionally valorized may be compared to the image of the Nenek Kebayan is present throughout layers of culture and belief. Some of the Nenek Kebayan to her international counterparts include appearing as a hideous old hag, living in a forest, possessing supernatural traits, being well versed in spells or even curses, knowledgeable in brewing potions and targets children as its primary victim. Furthermore, it is also noticeable that the Nenek Kebayan or the witch is synonymous with the forest, jungle, trees and isolation. From a perspective, the element of the forest may be read as the representation of the Nenek Kebayan, since the Nenek Kebayan's lair is in the forest and surrounded by trees. The motif of the Nenek Kebayan may also be seen throughout the chosen corpus as the prime antagonist that haunts the house's inhabitants by controlling the parameters of the haunted house.

The film Congkak revolves around the theme and motif of the spiritual guardians and transgressions. The film begins with Kasman, who buys a holiday home in a remote Kampung area just to spend a quality time together with his family since he is too busy with work. Kasman's family begin to experience series of occult events after they arrived at the summer house. Not only that, they also discovered an old Congkak. Upon their arrival, the hauntings increase and a frightening spiritual guardian in the form of the Nenek Kebayan appears. The Nenek Kebayan is the guardian of the land as well as the Congkak. She was the one who caused all of these hauntings. The Nenek Kebayan has a great fondness for Kasman's daughter Lisa and possessed her. Luckily, the Tok Imam came and banished the Nenek Kebayan in order to save Kasman and his family.

The film Al-Hijab also depicts a similar theme and motif which are spiritual guardians and the concept of transgression. The protagonist, Rafael, is obsessed with the idea of seeing ghosts to enhance his acting performance. He decides to meet Mak Itam, a local shaman, to help him open his Hijab (sixth sense) allowing him to see ghosts. Unfortunately, his attempt 
backfires when he is frequently haunted by ghosts and witches. At the film's resolution, Mak Itam dies, causing it to be impossible for Rafael's Hijab to be closed. He is doomed to be haunted by ghosts for the rest of his life.

In The Conjuring, the film fully utilizes the concept of the witch and restless spirit. The film initiates with the Parron's family, who have bought a new house in Rhode Island. As they begin to enter their new house, the youngest daughter April finds an old jukebox. Moments after the discovery of the jukebox, they start to experience mysterious and occult occurrences. Carolyn Parron decides to seek help from the Warrens, who happen to be paranormal investigators, to investigate these cases. One night, a demonic witch named Bathsheeba manifests herself as the guardian of the house and possesses Carolyn. A parallel to the possession in Congkak may be discerned here. The demon manages to control Carolyn's body with the intention to kill her own daughter, April. The Warrens have no choice but to exorcise the demon and this eventually helps Carolyn to break free from the demon's possession and she is therefore saved.

Based on the information provided, the chosen corpus has displayed the appearance of the Nenek Kebayan, the Witch and the utilization of the haunted house as the prime setting. There is some prominent research has been done regarding the subject of the haunted house. As highlighted by Bailey $(2009$, p.34) the haunted house is suggested to be psychological in nature. Bailey (2009, p34) further dictates that, other than the house becoming the avenue for the Manichean clash between good and evil, the external and the internal parts of the house also becomes the metaphor of the mirrored and distorted self. Bailey (2009, p.56) also suggested that the typical American or Hollywood horror films which deploys the haunted house as the primary setting has these four elements as its skeletal basis which comprises of the setting, the characters, themes and finally plot.

Another element that is worth mentioning is the haunted object, better known as the trigger object. It usually appeared in many cases of the haunted house scenario including in the chosen corpus. Alex Matsuo (2014, p.162) explicates that a trigger object is defined as the items can trigger, invite and causes paranormal occurrences. Matsuo (2014, p.162) further reflects that the trigger object may potentially be represented as toys, jewellery, antiques, statues and even portraits if the stated object has spiritual or paranormal aspect attached to them.

In 2017, a comparative study was conducted on the Malaysian and Hollywood haunted house films, pertaining to their filmic pattern. According to Ahmad Muhyiddin B Yusof, Ruzy Suliza Hashim, Noraini Mohd Yusof and Anita Harris Satkunananthan (2017, p.174) Malaysian and Hollywood haunted house films have a total of nine Plot Functions which are linear in pattern and leads towards the idea of the Manichean clash between good and evil. Ahmad Muhyiddin B Yusof et al (207, p.174) further explicate that Plot Function number 1 is called the Indicator followed by The Exploration, Disturbance, Information or Rumours, TheInvestigation, The Quarrel, Escalation, Discovery and finally The Vanquishing of Evil. Through the use of these plot functions, one may able to understand the film's structure and elements. The points of convergence are that the films differ in relation to the types of supernatural entities presented within their narratives and that their methods of warding off evil differ due to the intervention by Islamic and Christian belief systems. The implication of this study will reveal more avenues in further understanding the study of the haunted house especially in Malaysian and Hollywood horror films. 


\section{CONCEPTUAL FRAMEWORK}

This paper deploys a framework termed as the Structural Uncanny Haunted House Framework (SUHHF) and was introduced by Ahmad Muhyiddin B Yusof in 2019 to specifically analyse the nature of the haunted house's architectural traits and the house's function in delivering hauntings towards the inhabitants. According to Ahmad Muhyiddin B Yusof (2019, p.69) $S U H H F$ is basically consists of three aspects: 1) The Surmounted Corpse in which primarily analyses the overall appearance of the haunted house's architectural appearance on both external and internal layers of the house, 2) The Hazardous Transition is to scrutinize the function of the haunted house's transitional elements in channeling spectral hauntings to the inhabitants and finally 3) The Trojan Compartment examines the function of the hidden spaces in the house as the centre of hauntings. The construction of SUHHF is an adaptation of Joshua Comaroff's and Ong Ker-Shing's Typologies of Horror in 2013, which is connected to Vladimir's morphology of folktales and Nicholas Royle's writings on the Uncanny.

\section{THE SURMOUNTED CORPSE}

Ahmad Muhyiddin B Yusof (2019, p.91) explores the relationship between the landscape and atmosphere of the haunted house by coming out with the term The Surmounted Corpse. The notion of haunted house is seen as a duality where there is an opposite element that can be viewed in many aspects. Ahmad Muhyiddin B Yusof (2019, p.91) mentions abandonment which might be happening either directly or indirectly to manifest fear. The abandonment is not only restricted to physical objects such as broken blinking billboards and hanging signboards waiting to fall but also includes natural decay such as dried up flowers and the pungent scent of rotten meat, thus attracting flies and other vermin. The depiction of horror in the landscape is further seen in the architectural design particularly when traditional architecture (of any culture) meets modernity. Intriguingly, both cannot be assimilated together, and the modern motif restoration is perceived as a notorious invasion which is also a representation of good and evil. In the haunted houses depicted in the films, the personality of the new owners were shaped in the haunted house. Thus, they were illustrated in a positive manner with the intention to purify the house from the evil caused by the acts of previous owners. The patching of old and new conventions upon the house is termed as Architectural Invasion (Ahmad Muhyiddin B Yusof, 2019 p.123). An Architectural Invasion occurs when the house has been invaded or patched by different motifs such as modern design, vegetation or parts of the house is affected by the weather. The arrival of the new inhabitants to the house can also termed as Architectural Invasion as the new inhabitants brought along their belongings or renovating the house into a more modern taste, thus resulting to the Manichean clash between good and evil as the evil of the house feels threatened upon the invasion made by the inhabitants (Ahmad Muhyiddin B Yusof, 2019, p.115)

\section{THE TROJAN COMPARTMENT}

As suggested by Ahmad Muhyiddin B Yusof (2019, p.83) in an expansion of the concept by Cormaroff and Ong, the Trojan Compartment offers the idea of architectural deceit and explains the primary function of the hidden spaces in the haunted house. The notion of architectural deceit suggests that the external of the house is docile compared to threats, secrets or hideous motifs hidden in the interior. In relation to hidden spaces, this is a common or a must-have formula in both the Gothic and the haunted house setting as their primary function is to harbour secrets of the previous owner, trigger objects or dead bodies, the lair of spectral manifestations and the final puzzle piece which completes the mystery of the house (Bailey, 
1999; Curtis, 2008). Ahmad Muhyiddin B Yusof (2019, p.83) also comments that, hidden space marks the strongest hauntings compared to the rest of the house's parameter because such containment of secrets by the hidden spaces for a long period of time may result to the phenomenon of 'controlled repressed leakage' and uncontrolled repressed leakage' in which travels through the use of transitional elements towards the inhabitants.

\section{THE HAZARDOUS TRANSITION}

According to Ahmad Muhyiddin B Yusof (2019, p.70) the Hazardous Transition focuses on the typical transitional elements found in any haunted house films such as stairs, elevators, doors, windows, corridors and lightings. Furthermore, Ahmad Muhyiddin B Yusof $(2019,70)$ states that these transitional elements are usually explored and used by the spirits or ghosts to deliver their hauntings to the inhabitants. Common types of hauntings pointed by Mariconda (2007, p.269) appear in the form of light repetitive sounds such as "calls, moans, cries and screams, sings, snores, songs, footsteps, music, chains, rapping, glass breaking, and doors slamming." These methods of hauntings become the portal to invite the inhabitants to explore the secrets which causes the hauntings. Upon exploration, transitional elements become the key feature in discovering and revealing the hidden secrets that leads to the invitation of spectral infestations (Brittle, 2013). Ahmad Muhyiddin b Yusof $(2019$, p.71) opined that the nature of hauntings channeled through the transitional elements, are parallel to Freud's notion of the repressed (2003, p.147). Secrets which have been concealed behind closed doors or hidden rooms will begin to leak and travel through the transitional elements of the house. This phenomenon is termed as 'controlled repressed leakage' referring to light spectral disturbances and the 'uncontrolled repressed leakage' which refers to a severe form of hauntings.

\section{DISCUSSION}

Before deploying the SUHHF in an analysis of the three films, it is important to note that the analysis must begin with The Surmounted Corpse followed by The Trojan Compartment and The Hazardous Transition. This is because The Surmounted Corpse will reveal the overall parameter of the house and its relation to the image of architectural invasion made by the Nenek Kebayan. This is followed by The Trojan Compartment which furthers the understanding of the function of hidden spaces in the house as the nexus of hauntings and finally through the use of The Hazardous Transition to discern the channelling of hauntings through the route of the house's transitional elements from the hidden space(s) towards the inhabitants.

\section{THE SURMOUNTED CORPSE ANALYSIS}

\section{CONGKAK (2005)}

In Congkak, through the lens of the Surmounted Corpse, the haunted house is in the form of a two-storey villa resembling a traditional Malay house located in a remote orchard, close to a trench. The overall composition of the house is mainly wood. Although there is nothing out of the ordinary about the villa, there are two noticeable eerie elements which make the house mysterious and uncanny. Firstly, there is an old graveyard located near the house's parameter while the second one is the house is well maintained despite the house has been abandoned for over a year. These elements are noticed by Sufiah. She begins to display her worries and anxiety to her husband Kasman: 
Sufiah: "Su bukan ape bang, kita sudah beli rumah tu dari tahun lepas lagi, kita tak pernah pergi tempat tu."

Sufiah: "We have bought the house since last year, and we didn't have the chance to go there."

There are no horrific traits that may be initially identified within the internal parts of the villa except for the room that is located downstairs that is facing the dining hall. The room constantly emits the sound of a congkak game being played while the walls of the room is stained by dark green moss during night time. This terrifying change of the room occurs when the Nenek Kebayan is residing in the room.

AL-HIJAB (2011)

In Al-Hijab, the lair of the Nenek Kebayan is located in an abandoned quarters somewhere on the outskirts of the city.

Qiss: "Joe told me there is a hill, the old abandoned quarters. That place is very haunted. Nobody dares to enter there."

The primary traits of the quarters are overgrown by extreme vegetation and some part of the building has begun to crumble especially at the top floor of the quarters, the windows are broken and the walls have fallen down. In relation to the internal parts of the quarters, the staircase especially at the ground floor has been overpowered by crooked tree branches. Similar to the walls and other parts of the quarter's internals. The Nenek Kebayan is seen roaming within the internal parts of the quarters. It is clear here that the uncanny presence of the Nenek Kebayan is connected to the architectural configurations of her lair.

THE CONJURING (2013)

In the corpus The Conjuring, the house is in the form of a wooden two storey farm house, located remotely somewhere in Rhode Island, America. The parameter of the house is surrounded by many trees and a lake. An overall appearance, the house has no visible uncanny traits except for there is one massive crooked tree situated at a nearby lake. In the exposition of the film, Carolyn Perron does not suspect anything suspicious concerning the house. Furthermore, the Perrons bought the house to start a new life, hoping for a better future.

Carolyn Perron: Thanks for making this work, I know it is a lot to pay off. It's going to be great.

Roger Perron: I feel great already.

In relation to the internal aspect of the house, there is nothing out of the ordinary except for the hidden cellar. The hidden cellar stores the previous owner's belongings and the cellar is one of the witch's lair.

At this point, the houses in the chosen corpus have arrived at the point of convergence which are; the location of the house is either isolated or abandoned, surrounded or overgrown by vegetation and have at least one eerie or uncanny aspect that are nearby to the house such as an old cemetery, a lake and massive crooked tree. Through the lens of the Surmounted Corpse, it is clear that the house itself has been overpowered by the landscape and have a strong significant on the idea of an Architectural Invasion. As the house has been invaded by crawling vegetations that signifies the Nenek Kebayan or the witch in claiming the parameters of the house. Another aspect that is worth mentioning in regards to claiming spaces by the Nenek Kebayan or the witch is that somewhere within the parameter of the house, there are significant landmarks such as a massive crooked tree and an old cemetery. Appearance of such landmarks may be termed as spatial markings or the marking of landscapes are very powerful markers to display exclusion, defending territories and claiming ownership. (Tonkiss, 2005, p.141) Such 
an act of marking is synonym for humans to leave their own signature on a piece of document. Suggested by Green (2012) spatial markings usually have significant events behind its creation, and it is termed as spatial memories.

THE TROJAN COMPARTMENT AND HAZARDOUS TRANSITION ANALYSIS CONGKAK (2005)

In the corpus Congkak, there are countless number of hauntings or spectral disturbances that occurs at both external and internal parts of the Villa. Using the concept of The Trojan Compartment, the source of hauntings situated in a hidden room, opposite of the kitchen at the ground floor. The room showcases the motif of both controlled and uncontrolled repressed leakage such as the whispering of sounds, footsteps, screaming, and sounds of the Congkak board is being played and also the appearance of a shadow like figure. These leakages or hauntings travelled through the villa's transitional elements such as the house's corridors, stairs, windows and doors. Through concept of The Hazardous Transition, the transitional elements of the house become the route for the Nenek Kebayan to either travel or channels its evil deed to the victims. During the hauntings, it is revealed that the Nenek Kebayan is fond of Kasman's youngest daughter Lisa. In order to gain possession of Lisa, the Nenek Kebayan must first severe the connection between Lisa and the rest of her family through a series of psychological hauntings. Here the Nenek Kebayan only targets Lisa and Sufiah (the mother), making only Sufiah and Lisa experience the hauntings to the point that the rest of the family disbelieve Sufiah's assertions. Upon experiencing the hauntings, Sufiah tried to convince her family especially her husband to leave the house, unfortunately the husband disbelieved Sufiah, thus causing considerable stress and anxiety in her.

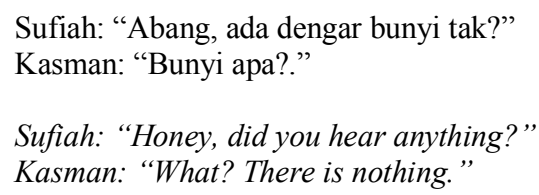

During such confusion, the Nenek Kebayan began makes its move to kidnap Lisa. During the confusion, the Nenek Kebayan lures Lisa using her demonic alluring whispers;

Nenek Kebayan: "Lisa, Lisa, marilah cu. Mari bermain congkak, Lisa."

Nenek Kebayan: "Lisa, Lisa, come here. Come and play the congkak, Lisa."

It is noticeable through the use of The Hazardous Transition and The Trojon Compartment, the Nenek Kebayan is using its trickery and mastery of space to actually separate and lure her victim. As the hauntings intensifies, the Nenek Kebayan actually lures Sufiah into her domain which is at the room opposite of the kitchen to possess her. Through this, the link between mother and daughter have been truly severed.

\section{$A L-H I J A B(2011)$}

In Al-Hijab, after Rafael requested the shaman to unlock his hijab, he revisited the abandoned quarters in order for him to experience real hauntings to escalate his acting career. Within the abandoned quarters, Rafael has been haunted by the Nenek Kebayan. The Nenek Kebayan is seen squatting at the main staircase. Through the use of The Hazardous Transition, it may be observed that the Nenek Kebayan is conquering the transitional elements of the quarter's internal areas such as the hallway, the stairs and the main entrance haunts and simultaneously restricting Rafael's movement from escaping the quarters. The spectral assault appears in the form of mysterious whisperings and the appearance of the Nenek Kebayan itself. Similar to 
Congkak, before the hauntings occurred the Nenek Kebayan actually attempted to lure Rafael to look at it by making a fading voice.

Nenek Kebayan: "Cu, cu, nak ke mana tu cu? Nenek nak ikut boleh? Pandang lah sini. $\mathrm{Cu}$, cu."

Nenek Kebayan: "Child, child, where are you going? Can I come along? Please look here. Child, child."

As Rafael turns his body towards the fading voice, the Nenek Kebayan scares Rafael by showing her old and crooked face.

\section{THE CONJURING (2013)}

In analysing The Conjuring through the lens of The Trojan Compartment, it is noticeable that the source of hauntings originated from the hidden cellar of the farmhouse. The cellar also displays the notion of controlled and uncontrolled repressed leakage. Disturbances that are channelled are viler compared to Congkak. Disturbances such as the emission of rancid smells, sleep paralysis, sudden low of temperature, psychokinesis, constant appearance of the witch or spiritual apparitions and finally possession may be discerned. The disturbances travelled from room to room, to identify the mother and possess her to murder the child. In this case, the witch specifically targets Caroline Perron and her daughters. Day by day, Caroline is slowly haunted and injured mentally and physically by the witch. This harm is evidenced by the bruises on her body.

\footnotetext{
Roger Perron: "Oh honey, you have another bruise here. Does that hurt?" Caroline Perron: "It's weird."

Roger Perron: "Oh honey do me a favour, go see a doctor for that."
}

The constant hauntings have made Caroline weak-minded, thus providing the means via which the witch could possess her. Repetitively, the behaviour of the witch to lure and haunt Caroline is reinforced. Once Caroline is fully possessed by the witch, she automatically kidnapped her daughters into the cellar to be sacrificed.

In summary, the analysis of The Trojan Compartment and The Hazardous Transition has resulted into two essential findings which are: 1) The Nenek Kebayan or the witch have used the hidden space as her main lair and 2) the house's transition has been overpowered by the Nenek Kebayan or the witch to channel her haunting, luring, manipulating the inhabitants and to restrict the inhabitant's movement in the house.

\section{CONCLUSION}

Based on the analysis, it is clear that the framework for this paper the Structural Uncanny Haunted House Framework (SUHHF) has proven its effectiveness in discerning and understanding the concept and the mechanics of the haunted house. The Surmounted Corpse is used to understand the overall appearance of the house, The Hazardous Transition focuses on the use of transitional elements of the house in channelling hauntings to the inhabitants and finally the Trojan Compartment helps to understand the use of hidden spaces as the main source of hauntings in the house. Although SUHHF primarily meant to understand the mechanics of the house, it can also be used to analyse the Nenek Kebayan's behaviour in claiming spaces of the house and simultaneously manipulating the house's parameters according to her likings. Although the threat imposed by the Nenek Kebayan or the witch is great and horrifying yet throughout the end of most haunted house episodes, the family did prevail in keeping each other safe. As illustrated by Ahmad Muhyiddin B Yusof, Ruzy Suliza Hashim, Noraini Md Yusof and Anita Harris Satkunananthan (2019, p.181) the notion of family is very prominent in the haunted house universe throughout the world and they are the representative and 
embodiment of positive values and on the contrary the haunted house is the embodiment of negativity and secrecy. The sense of horror and fear instilled by the uncanny nature of these houses and their even more uncanny inhabitants therefore reinforces the need for family and community.

\section{ACKNOWLEDGEMENTS}

Work on this article is funded by the following grant: GGP-2019-017 Climate-Based Literary Theory and Analytical Model for Indigenous Malaysian Communities impacted by Climate Change and Climate Migration, offered by the Centre for Research and Instrumentation, UKM.

\section{REFERENCES}

Bailey, D. (1999). Hollywood Nightmares: The Haunted House Formula in America Popular Fiction. Wisconsin: The University of Wisconsin Press.

Bane, T. (2012). Encyclopaedia of Demons in World Religions and Cultures. North Carolina: McFarland and Company. Inc.

Bane, T. (2016). Encyclopaedia of Spirits and Ghosts in World Mythology. North Carolina: McFarland and Company, Inc.

Brittany, M. (2017). Horror in Space: Critical Essays on a Film Subgenre. North Carolina: McFarland and Company.

Byron.G \& Punter. D. (2004). The Gothic. Oxford: Blackwell Publishing.

Cahn, L. V. (1996). Shakespeare the Playwright: A Companion to the Complete Tragedies, Histories, Comedies, and Romantics: Updated, With a New Introduction. Westport: Praeger.

Comaroff, J. \& Ong Ker-Shing. (2016). Horror in Architecture. Hong Kong: ORO Group Ltd.

Doolittle. A. A., Sajise, E. P. \& Dove, R. M. (2011). Beyond the Sacred Forest.: Complicating Conservation in Southeast Asia. USA: Duke University Press.

Dunning, L. (2010). Restless Spirits: Utah's Small-Town Ghost. Springville: CFI.

Faizal, M. (2014). Biografi Jin. Selangor: Yamani Angels SDN BHD.

Goldstein, E. D., Grider, A. S. \& Thomas, B. J. (2007). Haunting Experiences Ghosts in Contemporary Folklore. Utah: Utah State University Press.

Groom, N. (2012). The Gothic: A Very Short Introduction. Oxford: Oxford University Press.

Grinassi, R. (2003). The Witch's Familiar: Spiritual Partnerships for Successful Magic. Minnesota: Llewellyn Publications.

Guilley, R. (2008). The Encyclopaedia of Witches, Witchcraft and Wicca, Third Edition. New York: Facts on Fle, Inc.

Hamid, A. A. (2007). Meningkatkan Daya Fikir. Selangor: PTS Publications \& Distributors.

Harian Metro (2016). Histeria Nenek Harimau. Retrieved From https://www.pressreader.com/malaysia/harianmetro/20161111/283794263361494

Idham, A. (2008). Congkak. Film. Malaysia: Metrowealth.

Johns, A. (2010). Baba Yaga: The Ambiguous Mother and Witch of the Russian Folktale. New York: Peter Lang Publishing, Inc.

Kaay, V. F. \& Kaay, V. C. (2016). Horror Films by Subgenre: A Viewer's Guide. North Carolina: McFarland and Company.

Mariconda, J. M In Joshi S.T. (2007). Icons of Horror and the Supernatural: An Encyclopaedia of Our Worst Nightmares. London: Greenwood Press.

Matsuo, A. (2014). The Haunted Actor: An Exploration of Supernatural Belief through Theatre. Bloomington: Author House.

Muhyiddin Y, A. (2019). Haunted Structures: Haunted House Attributes In Malay And Hollywood Horror Films. Ph.D Dissertation. Bangi: Universiti Kebangsaan Malaysia.

Muhyiddin Y, A, Hashim, R S, Mohd Yusof, N, \& Harris Satkunananthan, A. (2017). Unravelling the Family Based Haunted House Film Patterns in Malay and American Haunted House Films. 3L: The Southeast Asian Journal of English Language Studies. Vol. 23 (4). 170-183.

Muhyiddin Y, A, Hashim, R S, Mohd Yusof, N. \& Harris Satkunananthan, A. (2019). Penelitian "Strategi Seram" Didalam Filem Rumah Berhantu di Malaysia dan Amerika. Jurnal Melayu Vol. 18 (1). 58-73.

Peletz, G. M. (1996). Reason and Passion: Representations of Gender in a Malay Society. Berkeley: University of California Press.

Pierre Andre. (2011). Al-Hijab. Film. Malaysia: Empat Semudra. 
Propp, V. (1968). Morphology of the Folktale. Texas: U of Texas P.

Puteh, O \& Said, A. (2007). Himpunan 366 Cerita Rakyat Malaysia. Kuala Lumpur: Utusan Publications \& Distributors Sdn Bhd.

Reyes, X. A. (ed). (2016). Horror: A Literary History. London: The British Library.

Royle, N. (2002). The Uncanny. Manchester: Manchester U P.

Krishnan, S. (2007). Reading the Global: Troubling Perspectives on Britain's Empire in Asia. New York: Colombia University Press.

Osman, S. A. (2020). Re(con)figuring the Nenek Kebayan Through Folktale Adaptation: Malaysian Folktales as Literary and Cultural Heritage. In Sharmani Patricia Gabriel, (ed). Making Heritage in Malaysia: Sites, Histories, Identities .London: Palgrave Macmillan.

Stang, M. A. (2015). Which Face of Witch: Self-representations of Women as Witches in Works of Contemporary British Women Writers. New Castle: Cambridge Scholars Publishing.

Yusof, Syafiq. (2015). Villa Nabila. Film. Malaysia: Skop Productions.

Wan. J. (2013). The Conjuring. Film. USA: Warner Bros.

Wan, M. H. (2015). Puaka Balai Gombak. Film. Malaysia: Showbiz.

Zakariya, B K. (2015). Kisah Mistik Hanya Dogengan, Boleh Pesong Akidah. Retrieved From https://www.bharian.com.my/node/55311 